\title{
SERUM LEVELS OF SOME METALS (IRON, MAGNISUM, ZINC AND LEAD) IN PATIENTS WITH CHRONIC OTITIS MEDIA AND ITS ASSOCIATION WITH CHOLESTEATOMA FORMATION
}

\author{
Mohamed Hussein Abdelazim*; Mahmoud Helmy Elsaied** \& Wesam Abdalsalam \\ Abdalwahab*** \\ *Al-Azhar University, Faculty of Medicine, New Damietta Ear, Nose and Throat department \\ **Al-Azhar University faculty of medicine New Damietta forensic medicine and clinical \\ toxicology department***Al-Azhar University faculty of medicine for girls forensic \\ medicine and clinical toxicology department \\ The corresponding author: Wesam Abdalsalam Abdalwahab \\ Email: $\underline{\text { w_abdalwahab@yahoo.com }}$
}

\begin{abstract}
$\underline{\text { ABSTRACT }}$
The association between middle ear diseases and metals serum levels in adult population is not well studied. So, the aim of this study was to estimate the serum levels of some metals (iron, magnesium, zinc and lead) in patients presented with chronic otitis media, and find if there is possible link with cholesteatoma formation or not. Patients and methods: This study was a across-sectional prospective study; conducted on 59 patients with chronic otitis media from ear, nose and throat department of Al-Azhar University Hospital (New Damietta) from January 2018 to December 2018 compared to the same number of age matched healthy controls. Serum iron, zinc, magnesium and lead levels were estimated to all patients and the healthy controls. Results: There was significant decrease of serum iron, magnesium and zinc while serum lead level was significantly increased in the patient's group as compared to the healthy controls. Cholesteatoma was found in $18(30.5 \%)$ of the patient's group. There was significant decrease of magnesium and significant increase of lead concentrations in patients who developed cholesteatoma. In addition, at the lead cut off values of $10 \mu \mathrm{g} / \mathrm{dl}$, cholesteatoma was more common in patients with high lead concentration. Conclusions: The results of this study showed that there were significant differences among patients and control and groups according to the studied metals levels. Serum levels of magnesium lead may play a role in the development of cholesteatoma. Recommendation: It is recommended to measure at least magnesium and lead levels in chronic otitis media patients and to add lead chelating agents, antioxidant and anti-inflammatory drugs with the antibiotics for its treatment, which could decrease free radical induced inflammatory alterations and prevent complications of otitis media. Further studies are required to ascertain the associations between the studied metals and the development of cholesteatoma.
\end{abstract}

KEYWORDS: Chronic otitis media, cholesteatoma, iron, magnesium, zinc, lead

\section{INTRODUCTION}

Chronic otitis media refers to chronic inflammation of tympanic membrane and middle ear space lasting more than 3 months ( Lo and Nemec.,2015) and it is a common health problem, that frequently encountered in daily otorhinolaryngology practice. It is 
more common in developing than developed countries (Vikram etal.,2008) and the blamed factors include - but not limited tolow socioeconomical status, limited or delayed access to medical care, poor hygiene and nutritional deficiencies (Akinpelu et al. ,2008).

Otitis media seems to affect more than 20 million subjects worldwide, and one fourth of those populations have a cholesteatoma (abnormal, noncancerous skin growth that can develop in the middle ear, behind the eardrum; its treatment almost always by surgical removal) (Aquino et al.,2011). The annual incidence of cholesteatoma in adults is about 9.2 per 100,000 adults. Middle ear cholesteatoma frequently found in patients younger than 50 years of age Olszewska et al.,2004).

Heavy metals are widely used in industry. However, its pollutant and toxic effects raise public concern. Lead $(\mathrm{Pb})$ for example as a non-biodegradable heavy metal can accumulate and build up concentrations in soil, sediments, plants, and aquatic organisms, leading to pollution of the food chain (Ashraf et al.,2011). On the other side, trace metals play a pivotal role to biochemical processes in the body and usually involved in immune-logical and inflammatory processes (Wacewicz et al.,2018).

The pathogenesis of chronic otitis media is fully clarified and many factors have been proposed to play a role; these factors include viral and/or bacterial infection, genetic predisposition, congenital anomalies, eustachian tube dysfunction, immunodeficiency, smoking and air pollution (Yadav et al.,2012). Oxidative stress was proposed as the pathophysiological mechanism of damage observed in chronic otitis media ( Karlidag et al.,2004).
In an interesting review, Elemraid et al., (2009) reported an association between middle ear diseases and single nutritional deficiency in pediatric population. However, they concluded that, this area of research is not well studied and needed future studies. In addition, such link in adults not well clarified, irrespective of theoretical benefit of supplementation.

So, the present study was designed to estimate the serum levels of some metals (iron, magnesium, zinc and lead) in patients presented with chronic otitis media, and find if there is possible link with cholesteatoma formation or not.

\section{MATERIALS \& METHODS}

Study design, place \& duration: A cross-sectional prospective study at ear, nose and throat department, New Damietta AlAzhar University Hospital from the first of January 2018 to the end of December 2018.

Study population and the inclusion criteria: This study was conducted on sixty patients who presented with signs and symptoms suggesting chronic otitis media (the diagnosis of chronic otitis media was based on clinical and otomicroscopic examinations). Another age and sex matched, apparently healthy subjects were included as control group, they were asymptomatic with normal physical examination and otomicroscopic evaluations.

One patient in the study group refused to give blood sample for analysis and thus was excluded, and only 59 patients were included in the statistical analysis.

The study protocol was approved by the local research and ethics committee of AlAzhar Faculty of Medicine (New Damietta) and Full informed written consent was taken from all patients and the control group after full explanation of the study protocol. 
Exclusion criteria: Patients with a history of occupational exposure to heavy metals, metal intoxication, who was living in metal contaminated areas, Also, patients with a history of chronic systemic disease (e.g., hypertension, diabetes mellitus, rheumatoid arthritis, hepatic disease, renal disease, or coronary artery disease); patients with immunosuppressive therapy, antioxidant therapy or vitamin supplementation were excluded from the study.

The collected data: Clinical characteristics including age, sex, the smoking behavior, the primary complaint and the presence or absence of cholesteatoma were recorded.

After full clinical and otomicroscopic examination, a venous blood sample of $5 \mathrm{cc}$ was drawn under aseptic condition from antecubital vein from each patient and the healthy controls. The blood samples were centrifuged at $3000 \mathrm{rbp}$ for 5 minutes. Serum iron, zinc, magnesium and lead levels were estimated by atomic absorption spectrophotometer as described by Sakai et al.,( 1998) at the Spectroscopy Department, faculty of Science, Al-Azhar University.

\section{Statistical analysis:}

Data were organized in an excel sheet and coded, then transferred to be analyzed by the IBM Statistical Package for Social Sciences version 21 (IBM®SPSS $®$ Inc.; Chicago, IL, USA).

Qualitative variables were expressed in the form of relative frequency and percent and groups compared by using the Chisquare test.

On the other side, mean and standard deviation (SD) were calculated for quantitative variables and to compare patients and healthy controls.
Student's t-test was used when comparing between two means. $\mathrm{P}$ value $\leq 0.05$ was considered significant.

\section{RESULTS}

Patients age ranged from 26 to 57 years, and with no significant difference between them and the control group as regards the mean age $(43.30 \pm 7.26$ vs $42.91 \pm 6.52$ years respectively). In addition, there was no significant difference between patients and control groups regarding sex distribution. Active and/or passive smoking were reported in $50.8 \%$ and $26.7 \%$ in patients and control groups respectively, with significant increase of smokers in the patients' group. The most common primary complaint in the patients' group was otalgia (50.8\%) followed by hearing loss (33.9\%) and otorrhea (15.3\%). Cholesteatoma was reported in $18(30.5 \%)$ of the patients' group (table 1).

Table (2) showed the comparison between the patients and the healthy controls according to the studied metals, there was statistically significant decrease in the levels of serum iron, magnesium and zinc while serum lead level was significantly increased in the patient's group when compared to the control group. In addition, when these levels were compared to the normal reference values, there was significant increase in the percentage of the subjects with iron, magnesium and zinc deficiency in the patients' group when compared to the control group. According to lead concentration (either on a cutoff of 5 or 10 $\mu \mathrm{g} / \mathrm{dl})$ there was significant increase in the percentage of the subjects with high lead concentration in the patients' group when compared to the control group (table 2).

When searching for correlation between the studied elements and the development of cholesteatoma, there was significant 
decrease of magnesium and significant increase of lead concentrations in patients who developed cholesteatoma. In addition, at a cut off values of $10 \mu \mathrm{g} / \mathrm{dl}$, cholesteatoma was more common in patients with high lead concentration

(table

$3)$.

Table (1): Comparison between patients and control groups according to demographic data, smoking, primary complaint and cholesteatoma formation using Chi-square test

\begin{tabular}{|c|c|c|c|c|}
\hline \multicolumn{2}{|l|}{$\begin{array}{l}\text { Groups } \\
\text { The studied } \\
\text { parameters }\end{array}$} & $\begin{array}{c}\text { Patients group } \\
\text { no }=59\end{array}$ & $\begin{array}{c}\text { Control group } \\
\text { no=59 }\end{array}$ & $\begin{array}{c}\text { P- } \\
\text { value }\end{array}$ \\
\hline \multicolumn{2}{|l|}{$\begin{array}{l}\text { Age: } \\
(\text { Mean } \pm \text { SD) } \\
\text { Range }(\mathbf{y})\end{array}$} & $\begin{array}{c}43.30 \pm 7.26 \\
26-57\end{array}$ & $\begin{array}{c}42.91 \pm 6.52 \\
30-57\end{array}$ & 0.75 \\
\hline \multirow[t]{2}{*}{$\operatorname{Sex}(\operatorname{no.}(\%))$} & Male & $33(55.9 \%)$ & $37(61.7 \%)$ & \multirow[t]{2}{*}{0.52} \\
\hline & Female & $26(44.1 \%)$ & $23(38.3 \%)$ & \\
\hline \multicolumn{2}{|c|}{$\begin{array}{l}\text { Active and/or passive smokers } \\
\text { no. }(\%)\end{array}$} & $30(50.8 \%)$ & $16(26.7 \%)$ & $0.007 *$ \\
\hline \multirow{3}{*}{$\begin{array}{l}\text { Primary complaint } \\
\text { no. }(\%)\end{array}$} & Hearing loss & $20(33.9 \%)$ & - & - \\
\hline & Otalgia & $30(50.8 \%)$ & - & - \\
\hline & Otorrhea & $9(15.3 \%)$ & - & - \\
\hline \multicolumn{2}{|c|}{$\begin{array}{l}\text { Cholesteatoma presence } \\
\text { no. }(\%)\end{array}$} & $18(30.5 \%)$ & - & - \\
\hline
\end{tabular}

\section{Abbreviations:}

(y), year; SD,

standard deviation;

no., number.

$\mathrm{P}$ value $\leq 0.05$ was considered significant. 
Table (2): Comparison between patients and control groups according to the studied metals levels (using t-test) and their status (using Chi-square test)

\begin{tabular}{|c|c|c|c|c|}
\hline \multicolumn{2}{|c|}{$\begin{array}{l}\text { Studied } \\
\text { metals }\end{array}$} & $\begin{array}{c}\text { Patients group } \\
\text { no }=59\end{array}$ & $\begin{array}{c}\text { Control group } \\
\text { no=59 }\end{array}$ & $\mathbf{P}$ \\
\hline \multicolumn{2}{|c|}{$\begin{array}{l}\text { Fe }(60-170 \mu \mathrm{g} / \mathrm{dl}) \\
\text { Mean } \pm \mathrm{SD} \\
\text { range }\end{array}$} & $60.25 \pm 12.71 ; 41-76$ & $\begin{array}{c}64.72 \pm 7.80 \\
42-79\end{array}$ & $0.022 *$ \\
\hline \multirow{2}{*}{$\begin{array}{l}\text { Fe status } \\
\text { (no. }(\%)\end{array}$} & Deficient & $23(39.0 \%)$ & $10(16.7 \%)$ & \multirow{2}{*}{$0.007 *$} \\
\hline & Normal & $36(61.0 \%)$ & $50(83.3 \%)$ & \\
\hline \multicolumn{2}{|c|}{$\begin{array}{l}\text { Mg (1.2-2.2mg/dl) } \\
\text { Mean } \pm S D \\
\text { range }\end{array}$} & $\begin{array}{c}1.21 \pm 0.36 \\
0.9-2.9\end{array}$ & $\begin{array}{c}1.52 \pm 0.25 \\
0.96-2.1\end{array}$ & $0.001 *$ \\
\hline \multirow{2}{*}{$\begin{array}{l}\text { Mg status } \\
\text { (no. }(\%)\end{array}$} & Deficient & $42(71.2 \%)$ & $11(18.3 \%)$ & \multirow{2}{*}{$0.001 *$} \\
\hline & Normal & $17(28.8 \%)$ & $49(81.7 \%)$ & \\
\hline \multicolumn{2}{|c|}{$\begin{array}{l}\text { Zn }(70-125 \mu \mathrm{g} / \mathbf{d l}) \\
\text { Mean } \pm \mathrm{SD} \\
\text { range }\end{array}$} & $\begin{array}{c}67.61 \pm 17.59 \\
51-120\end{array}$ & $\begin{array}{c}89.03 \pm 13.45 \\
55-110\end{array}$ & $0.001 *$ \\
\hline \multirow{2}{*}{$\begin{array}{l}\text { Zn status } \\
\text { (no. }(\%)\end{array}$} & Deficient & $48(81.4 \%)$ & $7(11.7 \%)$ & \multirow{2}{*}{$0.001 *$} \\
\hline & Normal & $11(18.6 \%)$ & $53(88.3 \%)$ & \\
\hline \multicolumn{2}{|c|}{$\mathbf{P b}$ mean $\pm \mathrm{SD}$} & $11.01 \pm 3.47$ & $6.66 \pm 2.17$ & $0.001 *$ \\
\hline \multirow{2}{*}{$\begin{array}{l}\text { Cut off } \\
\geq 5 \mu \mathrm{g} / \mathrm{dl}) \\
(\text { no. }(\%)\end{array}$} & Accepted & $4(6.8 \%)$ & $11(18.3 \%)$ & \multirow[b]{2}{*}{$0.05 *$} \\
\hline & High & $55(93.2 \%)$ & $49(81.7 \%)$ & \\
\hline \multirow{2}{*}{$\begin{array}{l}\text { Cut off } \\
\geq 10 \mu \mathrm{g} / \mathrm{dl}) \\
(\text { no. }(\%)\end{array}$} & Accepted & $21(35.6 \%)$ & $54(90.0 \%)$ & \multirow[b]{2}{*}{$0.001 *$} \\
\hline & High & $38(64.4 \%)$ & $6(10.0 \%)$ & \\
\hline
\end{tabular}

\section{Abbreviations:}

Fe: iron;

Mg: magnesium;

Zn: zinc;

$\mathrm{Pb}$ : lead;

SD: standard deviation

no., number.

$P$ value $\leq 0.05$ was considered significant. 
Table (3): Comparison between patients with cholesteatoma and patients without cholesteatoma according to the studied metals levels (using t-test) and their status (using Chi-square test).

\begin{tabular}{|c|c|c|c|c|}
\hline \multicolumn{2}{|l|}{$\begin{array}{l}\text { Groups } \\
\text { Studied } \\
\text { metals }\end{array}$} & $\begin{array}{c}\text { Patients with } \\
\text { cholesteatoma } \\
\text { no=18 }\end{array}$ & $\begin{array}{c}\text { Patients without } \\
\text { cholesteatoma } \\
\text { no }=41\end{array}$ & $\mathbf{P}$ \\
\hline \multicolumn{2}{|c|}{$\begin{array}{l}\text { Fe }(60-170 \mu \mathrm{g} / \mathrm{dl}) \\
\text { mean } \pm \mathrm{SD}\end{array}$} & $57.88 \pm 13.71$ & $61.29 \pm 12.27$ & 0.34 \\
\hline \multirow[t]{2}{*}{ Fe status } & $\begin{array}{l}\text { Deficient } \\
\text { no. }(\%)\end{array}$ & $10(55.6 \%)$ & $13(31.7 \%)$ & \multirow{2}{*}{0.08} \\
\hline & $\begin{array}{l}\text { Normal } \\
\text { no. }(\%)\end{array}$ & $8(44.4 \%)$ & $28(68.3 \%)$ & \\
\hline \multicolumn{2}{|c|}{$\begin{array}{l}\mathrm{Mg}(1.2-2.2 \mathrm{mg} / \mathrm{dl}) \text { mean } \\
\pm \mathrm{SD}\end{array}$} & $1.05 \pm 0.12$ & $1.28 \pm 0.40$ & $0.026 *$ \\
\hline \multirow[t]{2}{*}{$\begin{array}{l}\text { Mg } \\
\text { status }\end{array}$} & $\begin{array}{l}\text { Deficient } \\
\text { no. }(\%)\end{array}$ & $17(94.4 \%)$ & $25(61.0 \%)$ & \multirow{2}{*}{$0.009 *$} \\
\hline & $\begin{array}{l}\text { Normal } \\
\text { no. }(\%)\end{array}$ & $1(5.6 \%)$ & $16(39.0 \%)$ & \\
\hline \multicolumn{2}{|c|}{$\begin{array}{l}\text { Zn (70-125 } \boldsymbol{\mu g} / \mathbf{d l}) \\
\text { mean } \pm \text { SD }\end{array}$} & $61.38 \pm 10.88$ & $70.34 \pm 19.31$ & 0.07 \\
\hline \multirow[t]{2}{*}{$\begin{array}{l}\text { Zn } \\
\text { status }\end{array}$} & $\begin{array}{l}\text { Deficient } \\
\text { no. }(\%)\end{array}$ & $17(94.4 \%)$ & $31(75.6 \%)$ & \multirow{2}{*}{0.08} \\
\hline & $\begin{array}{l}\text { Normal } \\
\text { no. }(\%)\end{array}$ & $1(5.6 \%)$ & $10(24.4 \%)$ & \\
\hline \multicolumn{2}{|c|}{$\mathbf{P b}$ mean \pm SD } & $13.61 \pm 3.31$ & $9.87 \pm 2.91$ & $0.001 *$ \\
\hline \multirow[t]{2}{*}{$\begin{array}{l}\text { Cut off } \\
\geq 5 \mu \mathrm{g} / \mathrm{dl})\end{array}$} & $\begin{array}{l}\text { Accepted } \\
\text { no. }(\%)\end{array}$ & $1(5.6 \%)$ & $3(7.3 \%)$ & \multirow{2}{*}{0.80} \\
\hline & $\begin{array}{l}\text { High } \\
\text { no. }(\%)\end{array}$ & $17(94.4 \%)$ & $38(92.7 \%)$ & \\
\hline \multirow{2}{*}{$\begin{array}{l}\text { Cut off } \\
\geq \\
10 \mu \mathrm{g} / \mathrm{dl})\end{array}$} & $\begin{array}{l}\text { Accepted } \\
\text { no. }(\%)\end{array}$ & $1(5.6 \%)$ & $20(48.8 \%)$ & \multirow{2}{*}{$0.001 \%$} \\
\hline & $\begin{array}{l}\text { High } \\
\text { no. }(\%)\end{array}$ & $17(94.4 \%)$ & $21(51.2 \%)$ & \\
\hline
\end{tabular}

\section{Abbreviations:}

Fe: iron;

Mg: magnesium;

Zn: zinc;

$\mathrm{Pb}$ : lead;

SD: standard deviation

no., number.

$P$ value $\leq 0.05$ was considered significant. 


\section{DISCUSSION}

Results of the present work revealed that, adult patients with chronic otitis media had significantly decreased levels of iron, magnesium and zinc, and significant increase of lead when compared to healthy controls. In addition, patients who developed cholesteatoma had significant decrease of magnesium and significant increase of lead.

The present study is one of the fewer studies that investigate metals in chronic otitis media in adult populations. However, results of the present work are comparable to a study done by Elemraid et al., (2011) who evaluated the nutritional elements in association with chronic suppurative otitis media in pediatrics and found that, children with chronic suppurative otitis media had more undernutrition with lower levels of zinc, selenium and calcium concentrations.

The significant decrease of such elements could be participating in pathogenesis of chronic otitis media by affecting the immune system function, as these elements are known to keep immune system integrity by regulatory pathways or control of oxidative stress. Thus, their deficiency could increase the susceptibility to infection and hinder the response to treatment (Yang et al.,2012).

Going with results of the present work, Aydogan et al., ( 2013) reported significant reduction of serum zinc in otitis media with effusion. In addition, Bozan et al.,( 2017) reported that, serum $\mathrm{Zn}$ concentrations were significantly decreased in patients with chronic otitis media when compared with controls. They added that the reduction in serum zinc may lead to defect in appropriate immune response against otitis media.

The pivotal role of zinc in immune system could be exerted through its work as a cofactor in metallo-enzymes ( Valko et al.,2005). Aladag et al., ( 2007) reported that, zinc is also included in superoxide dismutase, which is one of the most important anti-oxidant enzymes. In addition, reduced serum zinc concentration decreased resistance to infection by suppressing activity of lymphocytes and neutrophils, decreased natural killer cell function, and decreased antibody response and phagocytosis.

This could explain the harmful effect of zinc deficiency in patients with chronic otitis media.

Consistent with results of the present work, Bozan et al., (2017) reported significant reduction of magnesium levels in patients with chronic otitis media. In addition, Grazyna et al., (2005) reported significant reduction of magnesium and iron in pediatrics with exudative otitis media when compared to healthy children.

On the other hand, Yue et al., (1992) reported significant high concentration of magnesium in middle ear fluids of patients with otitis media. The increased levels of magnesium in middle ear fluids could be explained by the antibacterial effects of magnesium reported in previous studies ( Romani .,2013).

Iron also, is a very important element for many metabolic process and normal cell growth. Iron deficiency usually associated with oxidative stress and development of several disease, especially infection as it has a bactericidal activity. Thus, its reduction could result in impaired immunity (Dayani et al.,2004).

These data could explain its pathogenic role in development of chronic otitis media in the present work.

In addition, Fakree.,(2015 )reported significant decrease of serum iron in Iraqi children with otitis media when compared to 
control group. Furthermore, Venugopal et al., (2018) documented the co-incidence of otitis media and iron deficiency in children and concluded that, iron deficiency anemia increases the susceptibility of children for recurrent episodes of ear infections

Aydogan et al., (2013) advocated that, in addition to antibiotic therapy in otitis media, it could be helpful to add antioxidant and anti-inflammatory drugs, which could decrease free radical induced inflammatory alterations and prevent complications of otitis media. This recommendation reinforces the assumption of pivotal role of antioxidants and metals in pathogenesis of otitis media.

Finally, the harmful effects of increased serum level of lead are well-documented on different systems. $\mathrm{Pb}$ exposure, even at very low doses, is associated with impairment of a wide range of body function. Different systems such as heart, kidneys, liver, nervous, endocrine, reproductive, and hematological systems are affected by $\mathrm{Pb}$ exposure (El Sawi and El Saied., 2013).

Farkhondeh et al., (2013) reported that, lead harmfully affects endothelial function and exaggerates the inflammatory response.

In consistency with the present work, Park et al., (2015) reported that, increased serum lead concentrations were associated with chronic otitis media.

In the present work, the primary complaint in the study group was otalgia, hearing loss and otorrhea in 50.8\%, 33.9\% and $15.3 \%$ respectively. These results are comparable to those reported by Almutairi et al., (2017) who reported that, the most common symptoms were ear pain $(76.6 \%)$, hearing impairment (59.6\%), and discharge $(29.8 \%)$.
In the present work, cholesteatoma was reported in $30.5 \%$ and this is slightly higher than those reported by Schmidt Rosito et al., (2017) who reported an incidence of $24.5 \%$ of patients with chronic otitis media. In addition, cholesteatoma was associated with decreased levels of magnesium and increased levels of lead. However, there was no studies in literature that deal with the same point. The possible associative role could be due to the oxidative stress and DNA damage exerted by increased serum lead in absence of protective role of magnesium and zinc with increased apoptosis of endothelial cells.

\section{CONCLUSIONS}

The results of this study showed that there were significant differences among patients and control groups according to the studied metals levels and that serum levels of magnesium and lead may play a role on development of cholesteatoma.

\section{RECOMMENDATION}

It is recommended to measure at least magnesium and lead level in chronic otitis media patients and to add lead chelating agents, antioxidant and anti-inflammatory drugs with the antibiotics for its treatment, which could decrease free radical induced inflammatory alterations and prevent complications of otitis media. Further studies are required to ascertain the associations between the studied metals and the development of cholesteatoma.

Limitation of the study: One limiting step of the present work is the crosssectional nature, by which it could not be clarified if the chemical changes are causes or results for the development of chronic otitis media. 


\section{REFERENCES}

Lo AC and Nemec SF. (2015): Opacification of the middle ear and mastoid: imaging findings and clues to differential diagnosis. Clin Radiol.; 70 (5): e1-13.

Vikram BK, Khaja $\mathbf{N}$ and Udayashankar SG (2008): Clinico-epidemiological study of complicated and uncomplicated chronic suppurative otitis media. J Laryngol Otol; 122:442-526

Akinpelu OV, Amusa YB and Komolafe EO ( 2008) : Challenges in management of chronic suppurative otitis media in a developing country. $\mathrm{J}$ Laryngol Otol; 122:16-20

Aquino JE, Cruz Filho NA and de Aquino JN. (2011): Epidemiology of middle ear and mastoid cholesteatomas: study of 1146 cases. Braz J Otorhinolaryngol; 77:341-7.

\section{Olszewska E, Wagner $M$ and Bernal-} Sprekelsen M, ( 2004): Etiopathogenesis of cholesteatoma. Eur Arch Otorhinolaryngol.; 261:6-24.

Ashraf MA, Maah MJ and Yusoff I. (2011): Heavy metals accumulation in plants growing in ex tin mining catchment. Int. J. Environ. Sci. Technol; 8, 401-416.

Wacewicz M, Socha K, Soroczynska J, Niczyporuk M, Aleksiejczuk P, Ostrowska J, et al., (2018): Selenium, zinc, copper, cu/Zn ratio and total antioxidant status in the serum of vitiligo patients treated by narrow-band ultraviolet-B phototherapy. J Dermatol Treat; 29:190-195
Yadav MK, Chae SW and Song JJ. (2012): In vitro streptococcus pneumoniae biofilm formation and in vivo middle ear mucosal biofilm in a rat model of acute otitis induced by $\mathrm{S}$. pneumoniae. Clin Exp Otorhinolaryngol; 5(3):139-144

Karlidag T, Ilhan N, Kaygusuz I, Keles E and Yalcin S. (2004): Comparison of free radicals and antioxidant enzymes in chronic otitis media with and without tympanosclerosis. Laryngoscope; 114(1):85-89

Elemraid MA, Mackenzie IJ, Fraser WD and Brabin BJ. (2009): Nutritional factors in the pathogenesis of ear disease in children: a systematic review. Ann Trop Paediatr; 29: 85-99.

Sakai T, Ushio K and Ikeya Y. (1998): Mobilized plasma lead as an index of lead body burden and its relation to the heme-related indices. Ind. Health; 36: 240-246.

Elemraid MA, Mackenzie IJ, Fraser WD, Harper G, Faragher B, Atef Z, et al., (2011): A case-control study of nutritional factors associated with chronic suppurative otitis media in Yemeni children. Eur J Clin Nutr; 65: 895902.

Yang CY, Wu ML, Chou YY, Li SY, Deng JF, Yang WC, et al.,(2012 ):Essential trace element status and clinical outcomes in long-term dialysis patients: a two-year prospective observational cohort study. Clin Nutr; 31: 630-6.

Aydogan F, Aydin E, Tastan E, Arslan N, Senes M, Unlu I, et al. (2013): Is there 
a relationship between serum levels of vitamin a, vitamin e, copper and zinc and otitis media with effusion in children? Indian J Otolaryngol Head Neck Surg;65: 594-7.

Bozan N, Dinc ME, Demir H, Turan M, Demir C, Arslan A, et al. (2017): Serum Trace Elements and Heavy Metal Levels in Patients Diagnosed with Chronic Otitis Media and Their Association with Surgical Treatment Outcomes. J Int Adv Otol; 13(3): 345-8

Valko M, Morris $H$ and Cronin MT. (2005): Metals, toxicity and oxidative stress. Curr Med Chem; 12: 1161-208.

Aladag I, Guven M, Eyibilen A, Sahin S and Köseoglu D. (2007): Efficacy of vitamin A in experimentally induced acute otitis media. Int $\mathrm{J}$ Pediatr Otorhinolaryngol; 71: 623-8.

18. Grazyna N, Piotr S and Krystyna C. (2005): Magnesium, Calcium and Iron levels in blood serum of children with otitis media with effusion. Journal of Elementologyy; 18 (1): 53-62.

Yue WL, Xu ZH, Fu YL, Ye QZ and Luo JY. (1992): Magnesium levels in middle ear fluids and sera in otitis media with effusion. Eur Arch Otorhinolaryngol; 249: 209-10.

Romani AM. (2013): Magnesium in health and disease. Met Ions Life Sci; 13: 4979 .

Dayani PN, Bishop MC, Black $K$ and Zeltzer PM. (2004): Desferoxamine (DFO)-mediated iron chelation: rationale for a novel approach to therapy for brain cancer. J Neurooncol; 67: 367-77.
Fakree NK. (2015): Measurement of Serum Trace Elements (Zinc, Copper, Magnesium and Iron) Concentrations in Pediatric Patients with Otitis Media with Effusion in Iraq. aqi J Pharm Sci,; .24(2): 72-75.

Venugopal A, Velankar HK, Mathew MS and Dabholkar YG. (2018): CoIncidence of Acute Otitis Media with Iron Deficiency Anemia in Children Below 12 Years of Age. Glob J Otolaryngol; 18(4): 1-4.

Ercal N, Neal R, Treeratphan P, Lutz PM, Hammond TC, Dennery PA et al. (2000): A role for oxidative stress in suppressing serum immunoglobulin levels in lead-exposed Fisher 344 rats. Arch Environ Contam Toxicol; 39:251256

El Sawi IR and El Saied MH. (2013): Umbilical Cord-blood Lead Levels and Pregnancy Outcome. Journal of Pharmacology and Toxicology; 8: 98104.

Farkhondeh T, Boskabady MH, Koohi MK, Sadeghi-Hashjin $G$ and Moin M. (2013): The effect of lead exposure on selected blood inflammatory biomarkers in guinea pigs. Cardiovasc Hematol Disord Drug Targets; 13: 45-9.

Park M, Lee JS, Lee JH, Oh SH and Park MK. (2015): Prevalence and risk factors of chronic otitis media: the Korean National Health and Nutrition Examination Survey 2010-2012. PLoS One; 10: e0125905.
Almutairi TS, Algayed HK, Alharbi FM, Alenezi HM, AlMutairi OM, Alzahrani $R$ and Al qudhybi AF. 
(2017): The Prevalence of Middle Ear Disease in The Adult Population. The Egyptian Journal of Hospital Medicine; 69 (8): 2955-2959

Schmidt Rosito LP, Lopes da Silva MN, Selaimen FA, Jung YP, Pauletti MG, et al. (2017): Characteristics of 419 patients with acquired middle ear cholesteatoma. Braz J

Otorhinolaryngol.;83(2):126---131 


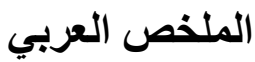

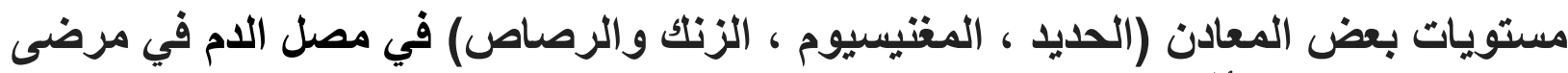
التهاب الأذن الوسطى المزمن ، ومدي ارتباطهم بتكوين الكوليستياتوما

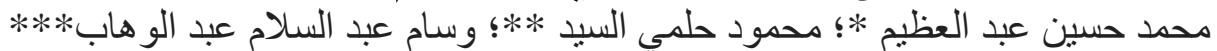

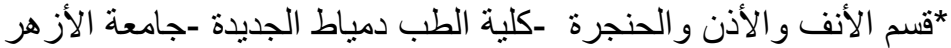

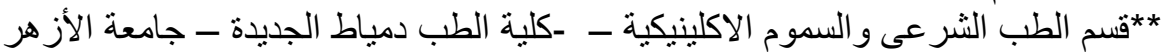

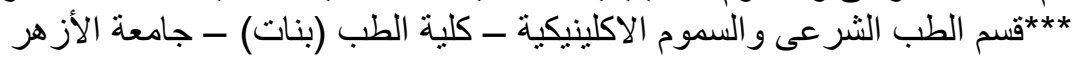

العلاقة بين أمر اض الأذن الوسطى ومستويات المعادن فى مصل الدم في البالغين لم تحظى بالقدر الكافى من مقدمة :

الهُف من هذه الدراسة :

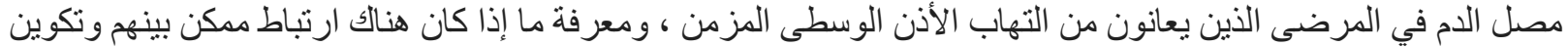
ورم الكوليستياتوما أم لالا. طريقة البحث: ورمبث:

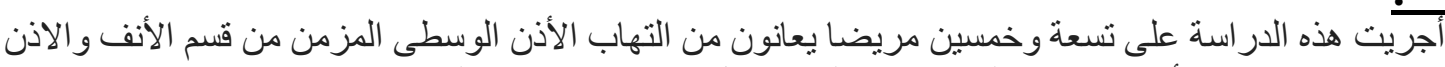

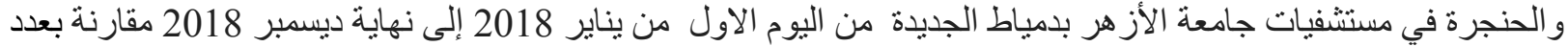

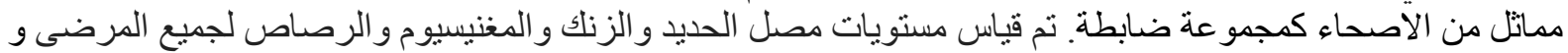
المجمو عة الضابطة.

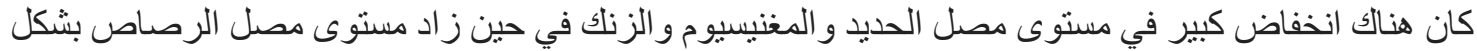

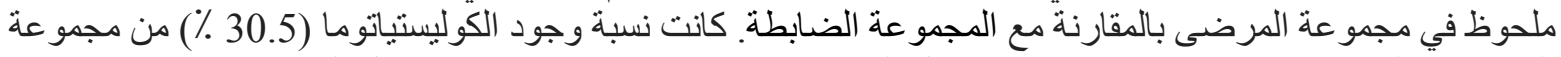

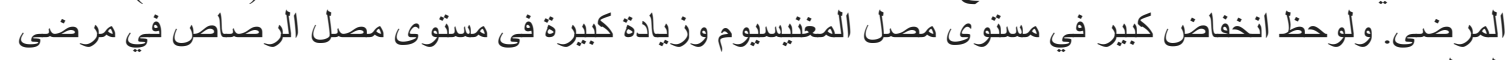
الكوليستياتوما.

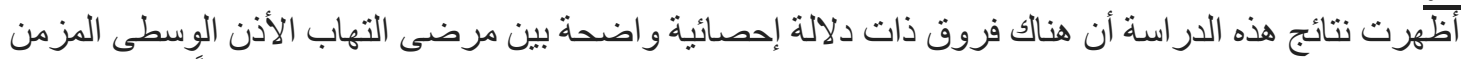
| الاستنتاجات:

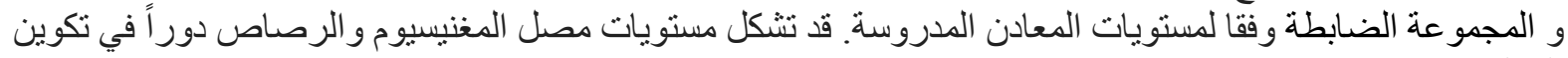
الكوليستياتوما. التوصيات :

يوصى بقياس مستوى مصل المغنيسيوم و الرصاص على الأقل في مرضى التهاب الأذن الوسطى المزمن و إضافة

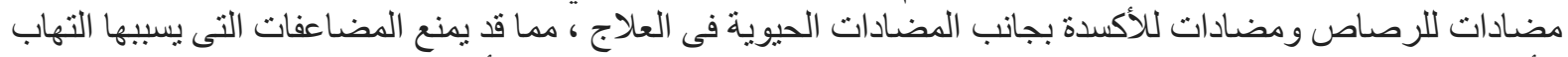

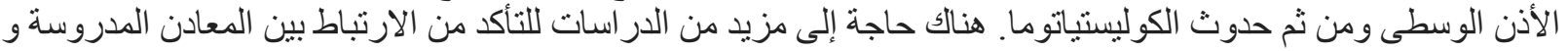

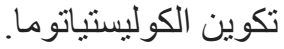

